\title{
A survey of Japanese quail (Coturnix coturnix japonica) farming in selected areas of Bangladesh
}

\author{
Abu Nasar Md. Aminoor Rahman, Md. Nazmul Hoque, Anup Kumar Talukder and Ziban Chandra Das
}

Department of Gynecology, Obstetrics \& Reproductive Health, Faculty of Veterinary Medicine \& Animal Science, Bangabandhu Sheikh Mujibur Rahman Agricultural University, Gazipur 1706, Bangladesh.

Corresponding author: Abu Nasar Md. Aminoor Rahman, e-mail: aminoor69@yahoo.com,

MNH: nazmul.hoque90@gmail.com, AKT: anupbau@gmail.com,ZCD: zibanbau@yahoo.com Received: 14-03-2016, Accepted: 30-07-2016, Published online: 07-09-2016

doi: 10.14202/vetworld.2016.940-947 How to cite this article: Rahman ANMA, Hoque MN, Talukder AK, Das ZC (2016) A survey of Japanese quail (Coturnix coturnix japonica) farming in selected areas of Bangladesh, Veterinary World, 9(9): $940-947$.

\begin{abstract}
Aim: To investigate the status, problems and prospects of Japanese quail (Coturnix coturnix japonica) farming in selected areas of Bangladesh.

Materials and Methods: The study was conducted in 14 districts of Bangladesh, viz., Dhaka, Narayanganj, Munshiganj, Mymensingh, Netrakona, Faridpur, Jessore, Khulna, Satkhira, Kushtia, Bogra, Naogaon, Comilla, and Sylhet during the period from July 2011 to June 2012. A total of 52 quail farmers were interviewed for data collection using a structured questionnaire. Focus group discussions were also carried out with unsuccessful farmers and those want to start quail farming. Workers of quail farms, quail feeds and medicine suppliers, quail eggs and meat sellers were also interviewed regarding the issue.
\end{abstract}

Results: Out of 52 farms, $86.5 \%$ were operated by male, $67.3 \%$ farmers did not receive any training and $92.3 \%$ farmers had no earlier experience of quail farming although $58.0 \%$ farmers primary occupation was quail farming. Most of the farms $(63.4 \%)$ were mixed in type having $\leq 5000$ birds of two or three varieties. About $80.7 \%$ farms were operated separately round the year with no other poultry and $83.0 \%$ farmers wanted to expand their farming. The average pullet weight $145.0 \pm 0.12$, $110.0 \pm 0.07,120.0 \pm 0.22$, and $128.0 \pm 0.17 \mathrm{~g}$; age at the first lay $46.0 \pm 0.04,42.0 \pm 0.31,42.0 \pm 0.09$, and $45.2 \pm 0.05$ days; rearing period $15.0 \pm 0.01,12.0 \pm 0.14,15.0 \pm 0.32$, and $15.2 \pm 0.18$ months; culling period $15.5 \pm 0.14,13.0 \pm 0.06,15.0 \pm 0.03$, and 15.4 \pm 0.26 months were for layer, parent stock, hatchery, and mixed farms, respectively. Most of the layer farms had an average egg production of $\leq 5000$ /day and net profit BDT $0.75 /$ egg. However, an average number of birds, hatchability and net profit per day-old-chick were $\leq 5000,76.8 \%$ and BDT 2.75 , respectively, in the hatchery. Broiler quails were sold at 30 days with mean weight of $110.8 \mathrm{~g}$ and net profit BDT 9.02/bird. The major constraints of quail farming were higher feed price, outbreak of endemic diseases, lack of proper knowledge, farmers training, proper market access, difficulties of parent stock collection, inadequate biosecurity practices, and limited access to veterinary care. Thus, a proper training on quail farming, bio-security management, and government subsidy on feeds could make quail farming sustainable in Bangladesh.

Conclusions: The study concludes that Japanese quail farming has enormous potentiality and could be an alternative to chicken farming particularly in providing gainful employment, supplementary income and as a valuable source of meat and egg, quail farming should be encouraged and promoted in Bangladesh.

Keywords: Bangladesh, Japanese quail, problems, prospects, status.

\section{Introduction}

Bangladesh is an agriculture-based developing country with approximately 140 million poultry [1]. The majority of these poultry are indigenous chickens and ducks [2]. The productive performance of this chickens is low and losses due to diseases and predators are high [3]. However, exotic pure breeds did not perform satisfactorily in scavenging system because of their higher nutritional demand and lower disease resistance [4]. Therefore, in addition to indigenous poultry, rural and semi-urban people need such

Copyright: Rahman, et al. Open Access. This article is distributed under the terms of the Creative Commons Attribution 4.0 International License (http://creativecommons.org/licenses/ by/4.0/), which permits unrestricted use, distribution, and reproduction in any medium, provided you give appropriate credit to the original author(s) and the source, provide a link to the Creative Commons license, and indicate if changes were made. The Creative Commons Public Domain Dedication waiver (http:// creativecommons.org/publicdomain/zero/1.0/) applies to the data made available in this article, unless otherwise stated. a suitable species of bird which can be reared easily with little investment and provide more economic return within a very short time.

Quails were small game birds that are now used for commercial production of eggs and meat [5], and they attain rapid sexual maturity have shorter incubation period and can produce up to four generations per annum, therefore making them the most suitable and effective poultry [6]. There are two species of quails suitable for breeding, viz., the Japanese quail (C. coturnix japonica) and the American or common quail (C. coturnix). Japanese quails belong to Phasianidae family and are migratory birds which migrate between Asia and Europe [5,6]. Japanese quails are the smallest member of poultry with immense potentiality [7], and therefore, used in commercial production for meat and egg [8,9]. Egg production is important in Far East and Asian countries, whereas meat production is important in Europe [10]. 
The Japanese quails are blessed with many desirable characteristics, viz., faster growth, early sexual maturity, high rate of egg production (300 egg/ annum), short generation interval (3-4 generations a year), small floor space (200-250 and $150-200 \mathrm{~cm}^{2}$, respectively in litter and cage system), less feed requirements (20-25 g/adult bird/day), short incubation period of hatching eggs, less feed cost, and less susceptibility to common chicken diseases [11-13]. Because of these encouraging economic traits, quail farming needs much lower capital investment as compared to chicken and duck with almost the same profit margin $[7,13]$. Japanese quail eggs have a high potential to be developed as a cheaper source of protein, especially in developing countries. In addition to being cheaper and delicious, quail eggs are rich in protein and good sources of folate, vitamin $\mathrm{B}_{12}$, pantothenic acid, iron, phosphorus, riboflavin and selenium [14]. Quail meat is tender, tasty, nutritious, and gaining popularity as a table delicacy among the consumers [15]. In regard to meat quality $(\mathrm{pH}$, color, and texture), the quail meat is similar to broiler meat [16]. The nutritional value of quail eggs is 3-4 times greater than chicken eggs since it contains more moisture, minerals than broiler meat and has less fat and fewer calories, forming an ideal food for health conscious consumers $[15,17]$. Due to its small size and short generation interval, the Japanese quail is also popular as laboratory animal [18].

Although, compared to chicken it is quite a new species of poultry in Bangladesh, however, it has already received renewed impetus with the passage of time [19]. Its immense potentialities as a new dimension in poultry farming have already been recognized in this country. However, till now, the status and the major problems of quail farming in Bangladesh are not properly explored. Therefore, the study was undertaken to obtain thorough and detailed information on the status, problems, and prospect of Japanese quail farming in selected areas of Bangladesh.

\section{Materials and Methods}

\section{Ethical approval}

All the procedures of the study were performed under the approval of Bangabandhu Sheikh Mujibur Rahman Agricultural University's Animal Experimentation Ethics Committee.

\section{Study area and farm management}

The study was conducted in 14 districts of Bangladesh, viz., Dhaka, Narayanganj, Munshiganj, Mymensingh, Netrakona, Faridpur, Jessore, Khulna, Satkhira, Kushtia, Bogra, Naogaon, Comilla, and Sylhet during the period from July 2011 to June 2012 (Figure-1). Bangladesh is vulnerable due to its position in the globe (Southeast Asian country). The climate is tropical; mild winter (October to March); hot, humid summer (March to June); humid, warm rainy monsoon (June to October). The country's total land area is about $147,570 \mathrm{~km}^{2}$, and geographic position

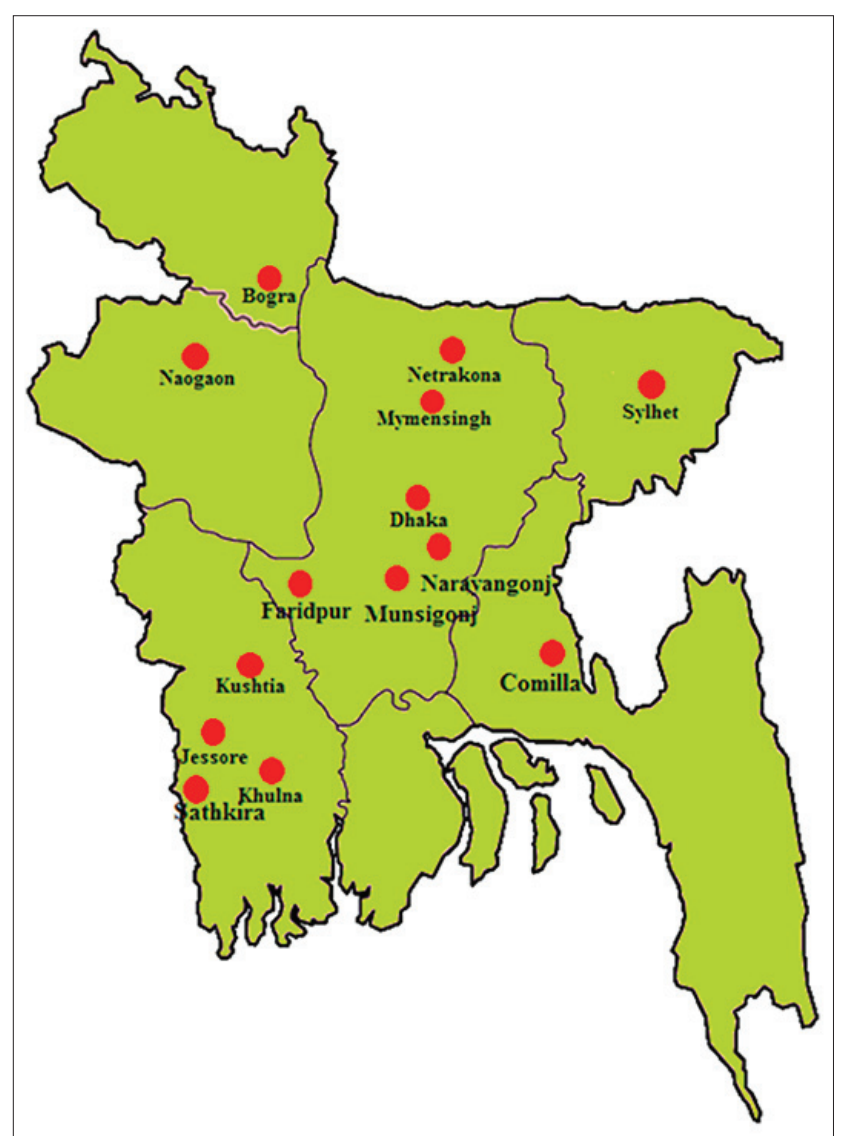

Figure-1: Distribution of Japanese quail farms in Bangladesh.

is latitude: $20^{\circ} 45^{\prime}$ to $26^{\circ} 40^{\prime} \mathrm{N}$, longitude: $88^{\circ} 05^{\prime}$ to $92^{\circ} 40^{\prime} \mathrm{E}$. The average annual rainfall varies from a maximum of $5690 \mathrm{~mm}$ in the northeast of the country to minimum of $1110 \mathrm{~mm}$ in the west. The day temperature ranges from 7 to $12^{\circ} \mathrm{C}$ in the cool months, and in the other months, it varies between 23 and $30^{\circ} \mathrm{C}$. All the farm houses were built using brick, net and tin, and floor rearing system was practiced for birds of all ages (brooding, growing and laying).

\section{Data collection}

The samples of this study were quail farmers (small, medium and large), including successful farmers, unsuccessful farmers those have already closed their farms, new farmers and interested peoples who want to start quail farming. A structured questionnaire schedule was prepared for interviewing the quail farmers in the selected areas of Bangladesh. This questionnaire was first piloted on a very small group of farmers, and then the questions were restructured in accordance with their responses. Focus group discussions were also carried out with unsuccessful farmers and those want to start quail farming. Workers of quail farms, quail feeds and medicine suppliers, quail eggs and meat sellers were also interviewed regarding the issue.

\section{Statistical analysis}

The data generated from this experiment were entered in Microsoft Excel (2007) worksheet, organized and processed for further analysis. Analysis 
was performed with the help of Statistical Packages for Social Sciences, version 11.5 for windows (SPSS, Inc., Chicago, IL, USA). Descriptive statistics were computed and histogram is drawn to figure out the net profit (gross income-gross cost) for individual circumstance.

\section{Results and Discussion}

To the best of our knowledge, there are no studies available on the present scenario, prospects and major constraints of Japanese quail farming in Bangladesh and this one might be the first ever study in this regard. The study was carried out in 52 quail farms and among these, 45 farms $(86.5 \%)$ were operated by male and quail farming was the primary occupation for $58.0 \%(30 / 52)$ farm holders. Most of the farmers $(69.2 \% ; 36 / 52)$ neither read any book on quail farming nor played any significant role in spreading the industry by motivating the jobless youth and distressed women providing training and technical support. The study also revealed that $67.3 \%$ farm holders did not receive any training and $92.3 \%$ farmers had no earlier experience of quail farming. Quail farming in
Bangladesh was started in 1992 and remained static for about one decade (1992-2003) since its inception, thereafter, gradually increased till 2009 (highest in 2009) and gradually declined thereafter (Figure-2). The reasons might be outbreak of epidemics, faulty management systems, higher price of feeds, the higher incidence of different infectious diseases, and lack of veterinary care.

The detail status of quail farming in Bangladesh has been shown in Table-1. Majority of the farmers (63.4\%) had a practice of mixed type quail farming. However, layer, parent stock and broiler or meat type farming were only practiced by $21.1 \%, 3.8 \%$ and $9.6 \%$ farmers, respectively. Mixed type quail farming is practiced worldwide because Japanese quails are suited for commercial rearing for egg and meat production under intensive management [20]. This is because of their hardiness and ability to thrive in small cages [21]; the relative short generation interval and cheaper cost of production [22]. In our study, about $78.8 \%$ farmers did not rear quail with other poultry. Most of the farmers had $\leq 5000$ birds with 2-3 varieties and reared quails separately. About $80.7 \%$ farms were

Table-1: Status of quail farming $(n=52)$ in Bangladesh.

\begin{tabular}{|c|c|c|}
\hline Criteria & Groups & n (\%) \\
\hline \multirow[t]{5}{*}{ Farm type } & Layer & $11(21.1)$ \\
\hline & Parent stock & $2(3.8)$ \\
\hline & Broiler/meat type & $5(9.6)$ \\
\hline & Hatchery & $1(1.9)$ \\
\hline & Mixed type & $33(63.4)$ \\
\hline \multirow[t]{2}{*}{ Whether reared with other poultry } & Yes & $11(21.1)$ \\
\hline & No & $41(78.8)$ \\
\hline \multirow[t]{4}{*}{ Farm size (number of quails) } & $<1000$ & $4(7.7)$ \\
\hline & $1001-2500$ & $15(28.8)$ \\
\hline & 2501-5000 & $17(32.7)$ \\
\hline & $5001-10,000$ & $7(13.4)$ \\
\hline \multirow[t]{4}{*}{ Number of breeds/varieties } & One breed/variety & $1(1.9)$ \\
\hline & Two breeds/varieties & $17(32.7)$ \\
\hline & Three breeds/varieties & $13(25.0)$ \\
\hline & Four breeds/varieties & $7(13.4)$ \\
\hline \multirow[t]{2}{*}{ Pattern of rearing } & Together & $22(42.3)$ \\
\hline & Separately & $30(57.7)$ \\
\hline \multirow[t]{2}{*}{ Farm operation } & Year round & $42(80.7)$ \\
\hline & Seasonal & $10(19.2)$ \\
\hline \multirow[t]{2}{*}{ Future plan } & Want to expand farm & $39(83.0)$ \\
\hline & Want to stop farming & $8(17.0)$ \\
\hline
\end{tabular}

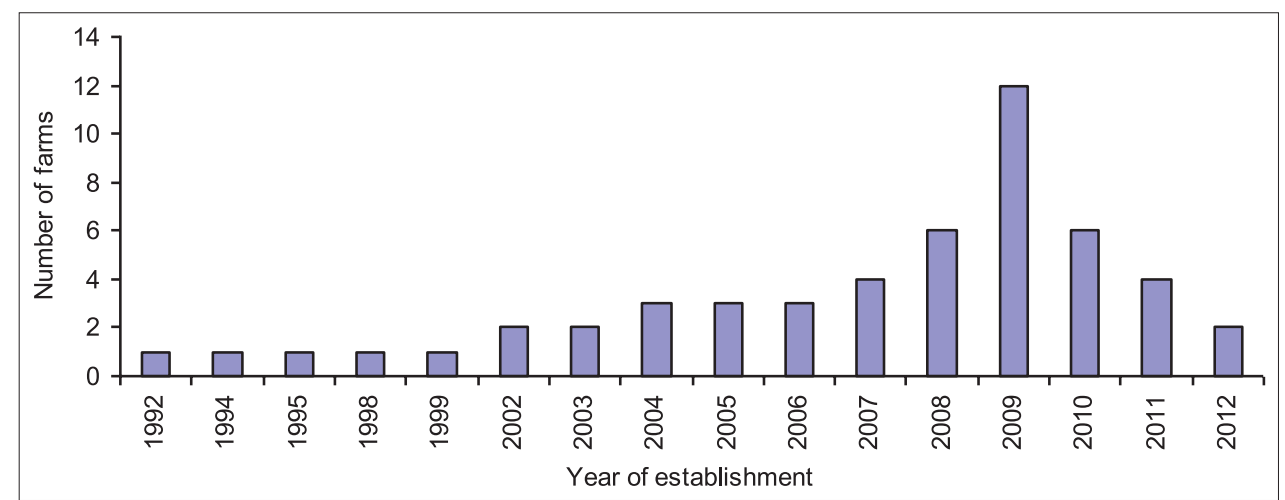

Figure-2: Establishment of quail farms in Bangladesh during the period from 1992 to 2012 [2,8,41]. 
operated round the year and $83.0 \%$ farmers wanted to expand their farming in future. The average pullet weight was $145.0 \pm 0.12,110.0 \pm 0.07,120.0 \pm 0.22$ and $128.0 \pm 0.17 \mathrm{~g}$ for layer, parent stock, hatchery and mixed farms, respectively. The average age at the first lay was $46.0 \pm 0.04,42.0 \pm 0.31,42.0 \pm 0.09$, and $45.2 \pm 0.05$ days; rearing period was $15.0 \pm 0.01$, $12.0 \pm 0.14,15.0 \pm 0.32$, and $15.2 \pm 0.18$ months; culling period $15.5 \pm 0.14,13.0 \pm 0.06,15.0 \pm 0.03$, and $15.4 \pm 0.26$ months for layer, parent stock, hatchery and mixed farms, respectively.

Most of the layer farms (95.2\%) had an average egg production of $\leq 5000 /$ day (Table-2). In a recent study, Singh [23] reported that on an average Japanese quail weighs about 8-9 $\mathrm{g}$ from hatching egg weight ranges from 10 to $12 \mathrm{~g}$, average body weight at 5-6 weeks is $180-200 \mathrm{~g}$, and adult body weight is 200$250 \mathrm{~g}$. However, there might be a significant variation in all the laying parameters among different local and imported stocks of Japanese quails [24]. The domestic quail shows rapid growth and attains sexual maturity at 5-6 weeks of age. Nowadays, meat type (broiler) quail strains are slaughtered at 5 weeks of age with a weight of 160-250 g [18,24]. Females enter into full lay at about 8-9 weeks of age. Layers are usually kept up to $8-10 \mathrm{~m}$ of age and produce about 300 eggs per year each with a weight of 7-11 $\mathrm{g}[18,25]$.

Detailed information on parent stock or broiler type quail farming has been shown in Table-3. Most of the farmers (47.8\%; parent stock and 57.5\%; broiler farms) have collected day-old-chick from their own farms. The parent stock farms had an average population of 7872 birds/farm with an average egg production of 5510/day (production rate $70.0 \%$ ) and male-female ratio found in most cases was 1:3. $65.0 \%$ parent stock farmers used incubator made from other sources having hatchery capacity of $>5000$ eggs/incubator and the average hatchability was $76.8 \%$ which was lower than the hatchability reported $84.4-91.8 \%$ based on different incubation

Table-2: Patterns of layer type quail farming $(n=42)$ in study areas.

\begin{tabular}{lcccc}
\hline Farming categories & Pullet weight (g) & $\begin{array}{c}\text { Age at first lay } \\
\text { (days) }\end{array}$ & $\begin{array}{c}\text { Rearing period } \\
\text { (months) }\end{array}$ & $\begin{array}{c}\text { Age of culling } \\
\text { (months) }\end{array}$ \\
\hline Layer & $145.0 \pm 0.12$ & $46.0 \pm 0.04$ & $15.0 \pm 0.01$ & $15.5 \pm 0.14$ \\
Parent stock & $110.0 \pm 0.07$ & $42.0 \pm 0.31$ & $12.0 \pm 0.14$ & $13.0 \pm 0.06$ \\
Hatchery & $120.0 \pm 0.22$ & $42.0 \pm 0.09$ & $15.0 \pm 0.32$ & $15.0 \pm 0.03$ \\
Mixed & $128.0 \pm 0.17$ & $45.2 \pm 0.05$ & $15.2 \pm 0.18$ & $15.4 \pm 0.26$ \\
Egg production/day & $<500$ & $501-1000$ & $1001-5000$ & $5001-10000$ \\
& $2(4.8 \%)$ & $16(38.0 \%)$ & $22(52.3 \%)$ & $2(4.8 \%)$ \\
\hline
\end{tabular}

Data were presented as mean \pm SE. SE: Standard error

Table-3: Status of parent stock and broiler farming in selected areas of Bangladesh.

\begin{tabular}{|c|c|c|}
\hline Criteria & Groups & n (\%) \\
\hline \multicolumn{3}{|l|}{ Parent stock farming ( $n=23$ farms) } \\
\hline \multirow[t]{3}{*}{ Collection of parent stock } & Own farm & $11(47.8)$ \\
\hline & Contact farm & $7(30.4)$ \\
\hline & Others sources & $5(21.7)$ \\
\hline Average number of parent stock/farm & $7872(500-50,000)$ & \\
\hline \multirow[t]{3}{*}{ Male female ratio } & $1: 2$ & $4(17.4)$ \\
\hline & $1: 3$ & $17(73.9)$ \\
\hline & $1: 4$ & $2(8.6)$ \\
\hline Average hatching egg production/day & $5510(350-15,500)$ & \\
\hline \multirow[t]{2}{*}{ Incubator source } & Self made & $8(34.8)$ \\
\hline & Other source & $15(65.2)$ \\
\hline \multirow[t]{4}{*}{ Hatcher capacity } & $2001-3000$ & $1(4.3)$ \\
\hline & $3001-4000$ & $4(17.4)$ \\
\hline & $4001-5000$ & $1(4.3)$ \\
\hline & $>5000$ & $17(73.9)$ \\
\hline Average hatchability & $76.8 \%(70-85)$ & \\
\hline \multicolumn{3}{|l|}{ Broiler farming ( $n=33$ farms) } \\
\hline \multirow[t]{3}{*}{ Type of farm } & Broiler & $5(15.1)$ \\
\hline & Meat type & $23(69.7)$ \\
\hline & Others & $5(15.1)$ \\
\hline \multirow[t]{4}{*}{ Collection of day old chick } & Own farm & $19(57.5)$ \\
\hline & Contact farm & $9(27.2)$ \\
\hline & Others & $4(12.1)$ \\
\hline & $\begin{array}{l}\text { Own+Contact } \\
\text { farmer }\end{array}$ & $1(3.0)$ \\
\hline Average marketing age (day) & $30(25-35)$ & \\
\hline Average number of broiler/farm & $5588(700-31,000)$ & \\
\hline \multirow{2}{*}{ Average weight $(\mathrm{g})$ at slaughter } & Undressed & $110.8(80-150)$ \\
\hline & Dressed & $76.93(60-100)$ \\
\hline
\end{tabular}


methods $[12,26]$. However, there were no significant differences in egg weight loss, hatchability, embryonic mortality, supply organ weights, spread of hatch or relative growth in relation to different treatment methods or incubation techniques [27]. Recent studies have shown that the mate choices of female quail are influenced by prior observations of males interacting with either females or other males as well as by direct interaction with males $[25,28]$. However, Gebreil [29] emphasized that for the optimum fertility male-female ratio must be between $1: 1$ and 1:3 for Japanese quails. In another study, Narinc et al. [30] observed the highest percentage of fertility in 1:1 (92.21\%) and 1:2 (91.18\%) male-female mating ratio. Nevertheless, it has also been reported in several studies that fertility was decreased below $80 \%$ for $1: 4$ and 1:5 mating ratios [30,31]. The mate choices of female Japanese quail can also be influenced by the behavior of conspecific females [32].

In our current study, most of the broiler quail farms $(69.7 \%)$ had an average size of 5588 birds/ farm and the average marketing age of these birds was 30 days (Table-3). The average weight for broiler quail is $110.8 \mathrm{~g}$ at slaughter and $76.9 \mathrm{~g}$ after dressing. The female birds were heavier in weight than the male both at slaughter and after dressing. The weight of the broiler quails in this study was somewhat lower than the weight reported in several studies in other countries $[20,33]$. In a previous study, Sultana et al. [34] found the highest weight of $162.5 \mathrm{~g}$ /quail and an average weight of $145.8 \mathrm{~g} / \mathrm{bird}$ experimentally in Bangladesh with different dietary nutrients supplementation. Our present findings coincide with several previous researchers who found an average body weight of 180-200 $\mathrm{g}$ at 5-6 weeks, and the females were heavier than males $[23,35]$. On the other hand, Ojo et al. and Seker et al. $[22,36]$ reported that female birds were significantly heavier than those of male counterpart and mean quail birds' body weights were 35.2 and $143.7 \mathrm{~g}$, at $2^{\text {nd }}$ and $8^{\text {th }}$ weeks.

A larger proportion of quail farms $(92.3 \%)$ has had the experience of disease prevalence, the proportion of healthy chick and death-in-shell was $92.1 \%$ and $13.5 \%$, respectively (Table-4). Even though most of the farmers $(73.0 \%)$ were well concerned about the general practice of biosecurity measures, only $52.0 \%$ farmers took veterinary care or advice whenever needed. Although a larger proportion of quail farms $(92.3 \%)$ have had the experience of disease prevalence, in most cases $(75.0 \%)$, the prevalence was less frequent. Diarrhea $(21.4 \%)$ was identified as most prevalent diseases in these farms followed by pneumonia (19.4\%), infectious coryza $(16.5 \%)$, Newcastle disease $(15.5 \%)$, dysentery $(5.8 \%)$, and avian influenza (4.9\%) (Figure-3). The proportions of healthy chick and death-in-shell were $92.1 \%$ and $13.5 \%$, respectively. Improvement in fertility could be achieved by improving environmental conditions and early embryonic mortality (death in shell) can significantly affected by breed, variety, size, shape of eggs, and prevalence of diseases in parent stock farms $[35,36]$. Fertility in Japanese quails can be affected by different factors such as mating ratio, parental age, rate of laying, climatic and management conditions, and younger birds represented higher significant percentages of fertility compared to those from older layer [13,37-39]. Although Japanese quails are comparatively more resistant to infectious diseases than chickens, some infectious diseases such as salmonellosis, coccidiosis, infectious coryza, enteric diarrhea, and pneumonia have

Table-4: Disease management practices in selected quail farms.

\begin{tabular}{llc}
\hline Criteria & Groups & n (\%) \\
\hline Disease problem in the farm & Yes & $48(92.3)$ \\
& No & $4(7.6)$ \\
Disease frequency & Less frequent & $39(75.0)$ \\
& Rare & $13(25.0)$ \\
Percent of shell death & $13.5 \%$ & \\
Percent of healthy chick & $92.1 \%$ & \\
Percent of unhealthy chick & $6.6 \%(1.5-20)$ & \\
Percent day-old-chick died & $2.8 \%(1-8)$ & \\
Vet/consultant's advice & Regularly & $1(1.9)$ \\
& At intervals & $18(34.7)$ \\
& Whenever needed & $27(52.0)$ \\
& Never & $6(11.5)$ \\
Bio-security practices & Strictly followed & $6(11.5)$ \\
& Generally followed & $38(73.0)$ \\
& Never followed & $8(15.3)$ \\
\hline
\end{tabular}

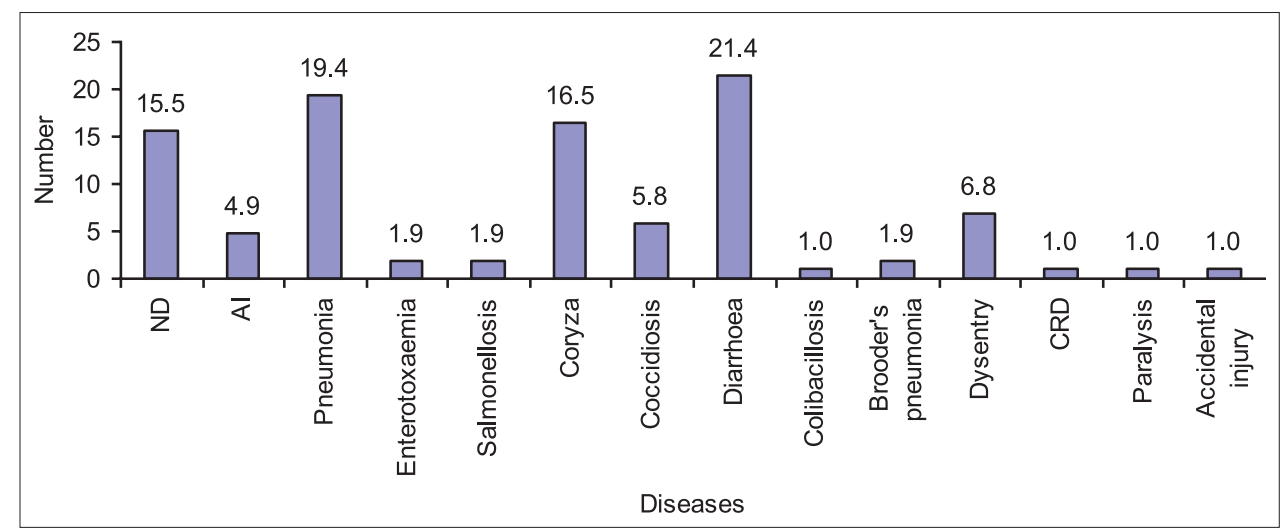

Figure-3: Prevalence of common diseases and disease conditions in quails ( $n=103$ cases). 
been reported in different earlier studies and in our current study.

This study revealed $\sim 50.0 \%$ layer farms had net profit of BDT $0.75 /$ egg. However, the net profit was BDT $1.00 /$ egg in $35.0 \%$ farms and BDT 0.25 0.50 /egg only in $15.0 \%$ farms. The minimum, maximum and average net profits were BDT 0.10, 1.00 and 0.69 , respectively (Figure-4). In the case of parent stock farming, $58.0 \%$ hatcheries had net profit of BDT 2.00-3.00/selling of a day-old-chick. The net profit of per day-old chick was BDT 1.50 in $14.0 \%$ hatcheries, BDT $3.50-3.50$ in $28.0 \%$ hatcheries. The minimum, maximum and average net profits were BDT 1.50, 4.00 and 2.75, respectively (Figure-5) and were higher in parent stock farming than the layer farming. Broiler quail farming was found most profitable in Bangladesh, and net profit per broiler was ranged from BDT 4.00 to 13.00 with an average of BDT 9.02. The net profit/broiler was BDT 5.00 in $8.0 \%$ farms, BDT 7.50 in $25.0 \%$ farms, BDT 10.00 in $34.0 \%$ farms, and BDT $\geq 12.5$ in $33.0 \%$ farms (Figure-6).

In spite of having enormous potentials of quail farming in Bangladesh has got many constraints. This study revealed that higher price (mean BDT 39.9/kg) of poultry feed $(94.2 \%)$ and outbreak of recent endemic diseases $(92.3 \%)$ were the major constraints for sustainable quail farming in Bangladesh. However, other constraints were lack of proper knowledge $(80.8 \%)$, difficulties in collection of parent stock $(78.8 \%)$, lack of proper market access by the farmers $(71.2 \%)$, lack of farmers training $(67.3 \%)$, inadequate bio-security practices $(88.2 \%)$, and limited access to veterinary care $(52.0 \%)$ (Table-5). The high cost of feeds is one of the major problems of commercial poultry production including Japanese quails and its cost usually ranged between $65 \%$ and $75 \%$ of the total production cost in Bangladesh [40].

\section{Conclusion}

Recognizing the enormous potentiality of Japanese quail as an alternative to chickens in providing gainful employment, supplementary income and as a valuable source of meat and egg, quail farming should be encouraged and promoted in Bangladesh. However, this study has explored

Table-5: Major constraints found in selected farms that limit the raising of quails.

\begin{tabular}{lc}
\hline Causes & $\begin{array}{c}\text { Number of farms } \\
(\%)\end{array}$ \\
\hline Lack of proper knowledge & $42(80.8)$ \\
Higher feed price & $49(94.2)$ \\
Collection of parent stock elsewhere & $41(78.8)$ \\
other than farmers owns farm & \\
Lack of proper market access & $37(71.2)$ \\
Lack of farmers training & $35(67.3)$ \\
Outbreak of endemic diseases & $48(92.3)$ \\
Inadequate bio-security practices & $46(88.3)$ \\
Limited access to veterinary care & $27(52.0)$ \\
\hline
\end{tabular}

the very poor situation and major constraints of Japanese quail farming throughout the country which brought about many challenges to the researchers, academicians and practicing veterinarians to adopt all the strategies to make quail farming economically and commercially viable in near future in Bangladesh.

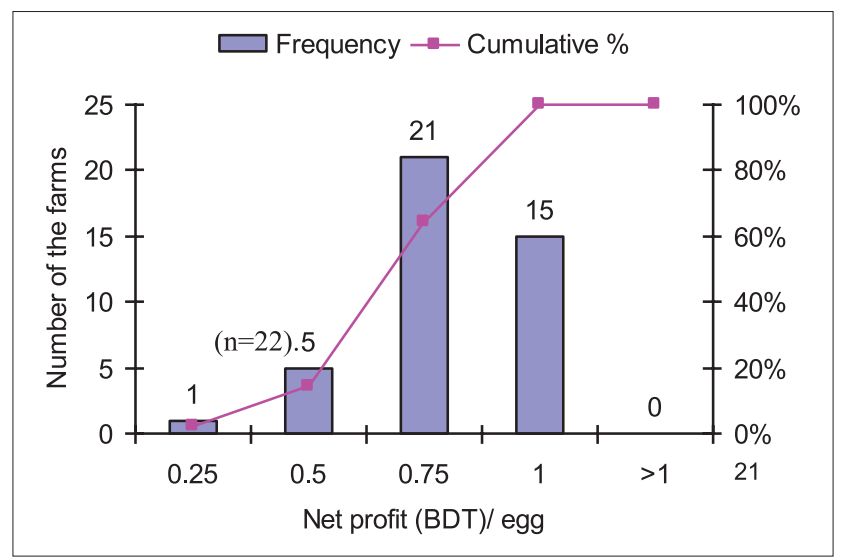

Figure-4: Frequency distribution of net profit (BDT) per egg in layer farms ( $n=42$ farms).

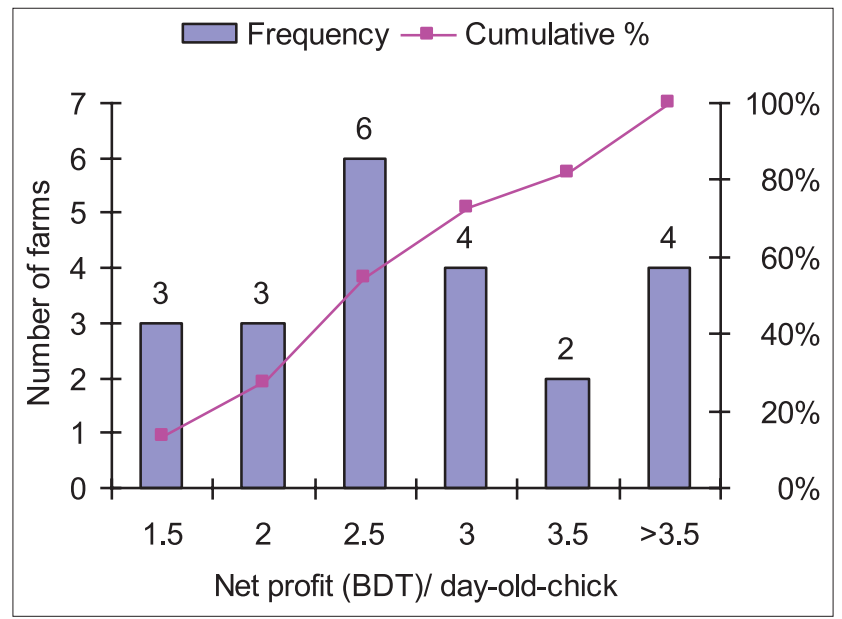

Figure-5: Frequency distribution of net profit (BDT)/dayold-chick in the quail hatcheries $(n=22)$.

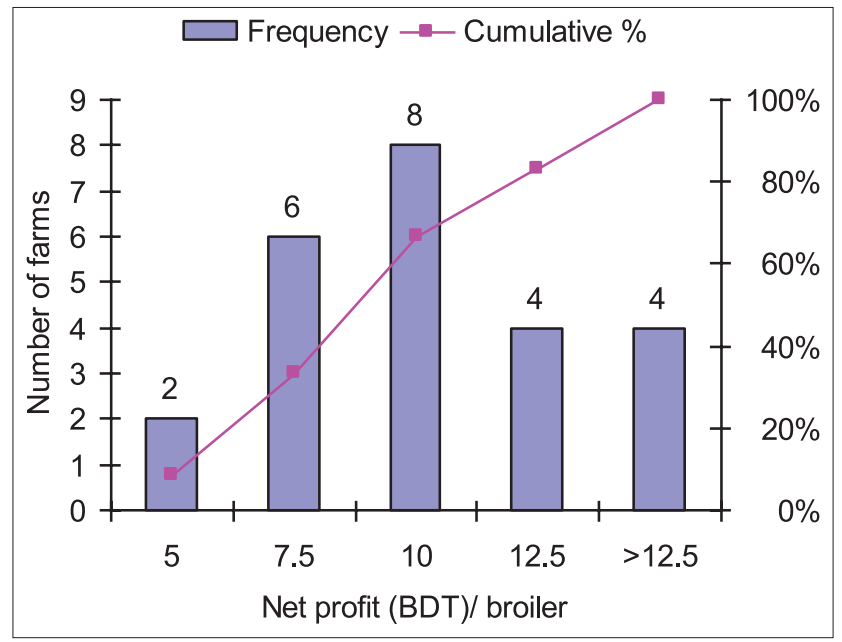

Figure-6: Frequency distribution of net profit (BDT)/broiler in broiler quail farms $(n=24)$. 


\section{Authors' Contributions}

ANMAR was the principal investigator of the project and designed the project and experiments, visited most of the quail farms, collected significant portions of the data and prepare the manuscript. $\mathrm{MNH}$ collected some of the data and helped in manuscript preparation and editing. AKT helped in the analysis of the data and ZCD helped in manuscript editing.

\section{Acknowledgments}

Sincere acknowledgment is extended to the Research Management Committee (RMC), Bangabandhu Sheikh Mujibur Rahman Agricultural University (BSMRAU), Gazipur-1706 and University Grants Commission (UGC), Bangladesh, for the Grant (UGC/RMC/25/2011-2012).

\section{Competing Interests} interests.

The authors declare that they have no competing

\section{References}

1. Rahman, M. (2000) Bangladesh poultry men need help. Poult. Int., 39: 15-16.

2. Das, S.C., Chowdhury, S.D., Khatun, M.A., Nishibori, M., Isobe, N. and Yoshimura, Y. (2008) Poultry production profile and expected future projection in Bangladesh. World's Poult. Sci. J., 64: 99-118.

3. Nakamura, R.M. (1990) A Livestock and Poultry Disease Control Program for Bangladesh. Checchi/USAID/BRAC, Dhaka.

4. Haque, M.E., Howlider, M.A.R. and Huque, Q.M.E. (1999) Growth performance and meat yield characteristics of native naked-neck and their crosses with exotic chicken. J. Appl. Anim. Res., 16: 81-86.

5. Onyewuchi, U.U., Offor, I.R. and Okoli, C.F. (2013) Profitability of quail bird and egg production in IMO state. Nig. J. Agric. Food Environ., 9(1): 40-44.

6. Saidu, S., Afanasyev, G., Popova, L., Komarchev, A. and Ibrahim, U. (2014) Dynamic of Reproductive Qualities of Japanese Quails. International Conference on Earth, Environment and Life Sciences, (EELS-2014) December 23-24, Dubai (UAE).

7. Minvielle, F. (2004) The future of Japanese quail for research and production. W. Poult. Sci. J., 60: 500-507.

8. Rahman, M.S., Rasul, K.M.G. and Islam, M.N. (2010) Comparison of the productive and reproductive performance of different color mutants of Japanese quails (Coturnix japonica). Proceedings of the Annual research Review Workshop, BLRI, Savar, Dhaka, Bangladesh. p50-56.

9. Ojedapo, L.O. and Amao, S.R. (2014) Sexual dimorphism on carcass characteristics of Japanese quail (Coturnix coturnix japonica) reared in derived Savanna zone of Nigeria. Int. J Sci., Environ. Technol., 3(1): 250-257.

10. Karapetyan, R. (2003) Biological and efficiency quality of quails. B. Bird., 8: 29-30.

11. Faitarone, A.B.G., Pavan, A.C., Mori, C., Batista, L.S., Oliveira, R.P., Garcia, E.A., Pizzolante, C.C., Mendes, A.A. and Sherer, M.R. (2005) Economic traits and performance of Italian quails reared at different cage stocking densities. Braz. J. Poult. Sci., 7(1): 19-22.

12. Aygun, A. and Sert, D. (2013) Effects of prestorage application of propolis and storage time on eggshell microbial activity, hatchability, and chick performance in Japanese quail (Coturnix coturnix japonica) eggs. Poult. Sci., 92: 3330-3337.
13. Jatoi, A.S., Sahota, A.W., Akram, M., Javed, K., Hussain, J., Mehmood, S. and Jaspal, M.H. (2013) Response of different body weights on blood serum chemistry values in four close-bred flocks of adult Japanese quails (Coturnix coturnix japonica). Pak. J. Zool., 45(5): 1215-1220.

14. Kalsum, U., Soetanto, H., Achmanu. and Sjofjan, O. (2012) Influence of a Probiotic containing Lactobacillus fermentum on the laying performance and egg quality of Japanese quails. Int. J. Poult. Sci., 11(4): 311-315.

15. Tunsaringkarn, T., Tungjaroenchai, W. and Siriwong, W. (2013) Nutrient benefits of quail (Coturnix coturnix japonica) eggs. Int. J. Sci. Res. Pub., 3(5): 2.

16. Narinc, D., Aksoy, T., Karaman, E., Aygun, A., Firat, M.Z. and Uslu, M.K. (2013) Japanese quail meat quality: Characteristics, heritabilities, and genetic correlations with some slaughter traits. Poult. Sci., 92: 1735-1744.

17. Wahab, M.A. (2002) Quails could reduce protein deficiency in poor countries. W. Poult., 18: 39.

18. Ophir, A.G., Persaud, K.N. and Galef, B.G.Jr. (2005) Avoidance of relatively aggressive male Japanese quail (Coturnix coturnix japonica) by sexually experienced conspecific females. J. Comp. Psychol., 119(1): 3-7.

19. Hoque, M.A., Ali, A., Bhuiyan, A.K.F. and Amin, M.R. (1996) Quantitative variation on of some economic traits in Japanese quail (Coturnix coturnix japonica). Bang. J. Anim. Sci., 25(1-2): 1-9.

20. Egbeyale, L.T., Fatoki, H.O. and Adeyemi, O.A. (2013) Effect of egg weight and oviposition time on hatchability and post hatch performance of Japanese quail (Coturnix coturnix japonica). Nig. J. Anim. Prod., 40: 102-110.

21. Odunsi, A.A., Rotimi, A.A. and Amao, E.A. (2007) Effect of different vegetable protein sources on growth and laying performance of Japanese quails (Coturnix coturnix japonica) in a derived savannah zone of Nigeria. W. Appl. Sci. J., 3(5): 567-571.

22. Ojo, V., Fayeye, T.R., Ayorinde, K.L. and Olojede, H. (2014) Relationship between body weight and linear body measurements in Japanese quail (Coturnix coturnix japonica). J. Sci. Res., 6(1): 175-183.

23. Singh, N.P. (2010) Quail Production and Management Technology. Personal communication (Extension Folder No. 40/2010), ICAR Research Complex for Goa, Ela, India.

24. Sultan, A.J., Waheed, A.S., Akram, M., Javed, K., Hussain, J., Mehmood, S. and Hayat, M.J. (2013) Hatching traits as influenced by different body weight categories in four close-bred flocks of Japanese quails (Coturnix coturnix japonica). Pak. J. Zool., 45(5): 1215-1220.

25. Ophir, A.G. and Galef, B.G.Jr. (2003) Female Japanese quail that 'eavesdrop' on fighting males prefer losers to winners. Anim. Behav., 66: 399-407.

26. Mehdi, B.G., Naser, M.S., Alireza, L. and Ayub, S.A. (2010) Effects of setting eggs small end up on hatchability and embryo mortality in Japanese quail (Coturnix coturnix japonica). Glob. Vet., 4(6): 592-594.

27. Yildirim, I., Aygun, A. and Sert, D. (2015) Effects of preincubation application of low and high frequency ultrasound on eggshell microbial activity, hatchability, supply organ weights at hatch, and chick performance in Japanese quail (Coturnix coturnix japonica) hatching eggs. Poult. Sci., 94(7): 1678-1684.

28. Persaud, K.N. and Galef, B.G.Jr. (2003) Female Japanese quail aggregate to avoid sexual harassment by conspecific males: A possible cause of conspecific cueing. Anim. Behav., 65: 89-94.

29. Gebreil, O.S.R. (2002) Effect of age, sex ratio, and male replacement on reproductive performance of quail. M.Sc. Thesis, Department of Animal Production, Faculty of Agriculture, Cairo University, Egypt. p25-27.

30. Narinc, D., Aygun, A. and Sar, T. (2013) Effects of cage type and mating ratio on fertility in Japanese quails (Coturnix coturnix japonica) eggs. T. I. J. Agric. Sci. Dev., 2(1): 4-7.

31. Brand, H.V., Parmetier, H.K. and Kemp, B. (2004) Effects 
of housing system (out door vs cages) and age of laying hens on egg characteristics. Br. J. Poult. Sci., 45(6): 745-752.

32. White, D.J. and Galef, B.G.Jr. (1999) Mate-choice copying and conspecific cueing in Japanese quail, Coturnix coturnix japonica. Anim. Behav., 57: 465-473.

33. Banerjee, S. (2010) Carcass studies of Japanese quails (Coturnix coturnix japonica) reared in hot and humid climate of Eastern India. W. Appl. Sci. J., 8(2): 174-176.

34. Sultana, F., Islam, M.S. and Howlider, M.A.R. (2007) Effect of dietary calcium sources and levels on egg production and egg shell quality of Japanese quail. Int. J. Poult. Sci., 6(2): 131-136.

35. Magda, I., Samaha, A., Sharaf, M.M. and Hemeda, S.A. (2010) Phenotypic and genetic estimates of some productive and reproductive traits of Japanese quails. Egypt. Poult. Sci., 30: 875-892.

36. Seker, I., Ekmen, F., Bayraktar, M. and Kul, S. (2004) The effects of parental age and mating ratio on egg weight, hatchability and chick weight in Japanese quail. J. Anim. Vet. Adv., 3: 424-430.

37. Rizk, R.E., Nadia, A., El-Sayed, E.H.A., Shahein, H. and Shalan, M. (2008) Relationship between egg shell, egg shell membranes and embryonic development through different egg production periods in two developed chicken strains. Egypt. J. Poult. Sci., 28: 535-551.

38. Daikwo, S.I., Dim, N.I. and Momoh, M.O. (2011) Hatching characteristics of Japanese quail eggs in a tropical environment. Int. J. Poult. Sci., 10(11): 876-878.

39. Raji, A.O., Mbap, S.T. and Kwari, I.D. (2015) Fertility and hatchability of Japanese quail eggs under semi arid conditions in Nigeria. Nig. J. Anim. Prod., 42(1): 41-49.

40. Haq, A. and Akhtar, M. (2004) Poultry Farming. Vol. 260. Higher Education Commission, Islamabad, Pakistan. p221-231.

41. Siddiqui, S.A. and Mondal, M.A.S. (1996) Economics of Japanese quail farming in Dhaka Metropolitan City. Bang. J. Agric. Econ., 19(1-2): 71-84.

$* * * * * * * *$ 